\title{
Isolation and Characterization of the Homoacetogenic Thermophilic Bacterium Moorella glycerini sp. nov.
}

\author{
ALEXANDER SLOBODKIN, ${ }^{1}$ ANNA-LOUISE REYSENBACH, ${ }^{2}$ FRANK MAYER, ${ }^{3}$ \\ AND JUERGEN WIEGEL ${ }^{1 *}$ \\ Department of Microbiology and Center for Biological Resource Recovery, University of Georgia, Athens, \\ Georgia 30602-2605'; Department of Biochemistry and Microbiology, Cook College, Rutgers \\ University, New Brunswick, New Jersey 08903²; and Department of Microbiology, \\ University of Göttingen, 37077 Göttingen, Germany ${ }^{3}$
}

\begin{abstract}
A thermophilic, anaerobic, spore-forming bacterium (strain JW/AS-Y6 ${ }^{\mathrm{T}}$ ) was isolated from a mixed sediment-water sample from a hot spring (Calcite Spring area) at Yellowstone National Park. The vegetative cells of this organism were straight rods, 0.4 to $0.6 \mathrm{by} 3.0$ to $6.5 \mu \mathrm{m}$. Cells occurred singly and exhibited a slight tumbling motility. They formed round refractile endospores in terminal swollen sporangia. Cells stained gram positive. The temperature range for growth at pH 6.8 was 43 to $65^{\circ} \mathrm{C}$, with optimum growth at $58^{\circ} \mathrm{C}$. The range for growth at $60^{\circ} \mathrm{C}\left(\mathrm{pH}^{60 \mathrm{C}}\right.$; with the $\mathrm{pH}$ meter calibrated at $60^{\circ} \mathrm{C}$ ) was 5.9 to 7.8 , with an optimum pH ${ }^{60 \mathrm{C}}$ of $6.3^{\circ}$ to 6.5. The substrates utilized included glycerol, glucose, fructose, mannose, galactose, xylose, lactate, glycerate, pyruvate, and yeast extract. In the presence of $\mathrm{CO}_{2}$, acetate was the only organic product from glycerol and carbohydrate fermentation. $\mathrm{No}_{2}$ was produced during growth. The strain was not able to grow chemolithotrophically at the expense of $\mathrm{H}_{2}-\mathrm{CO}_{2}$; however, suspensions of cells in the exponential growth phase consumed $\mathrm{H}_{2}$. The bacterium reduced fumarate to succinate and thiosulfate to elemental sulfur. Growth was inhibited by ampicillin, chloramphenicol, erythromycin, rifampin, and tetracycline, but not by streptomycin. The $\mathbf{G}+\mathrm{C}$ content of the DNA was $54.5 \mathrm{~mol} \%$ (as determined by high-performance liquid chromatography). The 16S ribosomal DNA sequence analysis placed the isolate in the Gram type-positive Bacillus-Clostridium subphylum. On the basis of physiological properties and phylogenetic analysis we propose that the isolated strain constitutes a new species, Moorella glycerini; the type strain is JW/AS-Y6 (= DSM $11254=$ ATCC 700316).
\end{abstract}

Under thermobiotic conditions, a large number of anaerobic microorganisms utilize a variety of biopolymers, including proteins, cellulose, xylan, starch, pectin, and sugars (30). Thermophiles involved in anaerobic degradation of lipids and of products of lipid degradation, such as long-chain fatty acids and glycerol, are less studied. A number of thermophilic sulfatereducing bacteria which can degrade long-chain fatty acids or glycerol have been isolated $(18,21)$. Recently, Thermosyntropha lipolytica, the first lipolytic, anaerobic thermophile which utilizes the liberated short- and long-chain fatty acids, but not glycerol in syntrophic cocultures with a methanogen, has been described (24). Among the thermophilic fermentative anaerobes Fervidobacterium nodosum (20) and Thermoanaerobacter wiegelii (4) utilize glycerol as a growth substrate; however, metabolic products and pathways of glycerol utilization for these organisms have not been reported.

In this paper we describe an anaerobic (eu)bacterial thermophilic bacterium, Moorella glycerini sp. nov., isolated from a hot spring at Yellowstone National Park, which utilizes glycerol as a growth substrate.

\section{MATERIALS AND METHODS}

Source of organism. The strain was isolated from a mixed sediment-water sample collected from a freshwater hot spring in the Calcite Spring area of Yellowstone National Park, Wyo., in September 1995. The temperatures at sampling points were 65 to $80^{\circ} \mathrm{C}$, and the $\mathrm{pH}$ determined at $25^{\circ} \mathrm{C}$, with the $\mathrm{pH}$ meter calibrated at $25^{\circ} \mathrm{C}\left(\mathrm{pH}^{25 \mathrm{C}}\right)$, was around 6.5 .

Media and cultivation. A basal medium used for enrichment, isolation, and cultivation was prepared by the modified Hungate technique (15) under a $\mathrm{CO}_{2}$ $(100 \%)$ gas phase. The basal medium contained (per liter of deionized water)

\footnotetext{
* Corresponding author. Mailing address: Department of Microbiology, 215 Biological Sciences Building, University of Georgia, Athens, GA 30602-2605. Phone: (706) 542-2651. Fax: (706) 542-2651 or -2674. E-mail: jwiegel@uga.cc.uga.edu.
}

$0.33 \mathrm{~g}$ of $\mathrm{KH}_{2} \mathrm{PO}_{4}, 0.33 \mathrm{~g}$ of $\mathrm{NH}_{4} \mathrm{Cl}, 0.33 \mathrm{~g}$ of $\mathrm{KCl}, 0.33 \mathrm{~g}$ of $\mathrm{MgCl}_{2} \cdot 2 \mathrm{H}_{2} \mathrm{O}, 0.33 \mathrm{~g}$ of $\mathrm{CaCl}_{2} \cdot 2 \mathrm{H}_{2} \mathrm{O}, 2.0 \mathrm{~g}$ of $\mathrm{NaHCO}_{3}, 0.5 \mathrm{~g}$ of $\mathrm{Na}_{2} \mathrm{~S} \cdot 9 \mathrm{H}_{2} \mathrm{O}, 0.5 \mathrm{~g}$ of yeast extract (BBL), $0.001 \mathrm{~g}$ of resazurin, $3.0 \mathrm{ml}$ of glycerol, $10 \mathrm{ml}$ of a vitamin solution (31), and $1 \mathrm{ml}$ of a trace element solution. The trace element solution contained (per liter) $2.0 \mathrm{mmol}$ of $\left(\mathrm{NH}_{4}\right)_{2} \mathrm{Fe}\left(\mathrm{SO}_{4}\right)_{2} \cdot 6 \mathrm{H}_{2} \mathrm{O}, 2.0 \mathrm{mmol}$ of $\mathrm{Na}_{2} \mathrm{SO}_{4}, 1.0 \mathrm{mmol}$ of $\mathrm{CoCl}_{2} \cdot 6 \mathrm{H}_{2} \mathrm{O}, 1.0 \mathrm{mmol}$ of $\mathrm{NiCl}_{2} \cdot 6 \mathrm{H}_{2} \mathrm{O}, 0.5 \mathrm{mmol}$ of $\mathrm{MnCl}_{2} \cdot 4 \mathrm{H}_{2} \mathrm{O}, 0.5 \mathrm{mmol}$ of $\mathrm{ZnSO}_{4} \cdot 7 \mathrm{H}_{2} \mathrm{O}, 0.5 \mathrm{mmol}$ of $\mathrm{Na}_{2} \mathrm{SeO}_{3}, 0.1 \mathrm{mmol}$ of $\mathrm{Na}_{2} \mathrm{MoO}_{4} \cdot 2 \mathrm{H}_{2} \mathrm{O}, 0.1$ mmol of $\mathrm{Na}_{2} \mathrm{WO}_{4} \cdot 2 \mathrm{H}_{2} \mathrm{O}, 0.1 \mathrm{mmol}$ of $\mathrm{H}_{3} \mathrm{BO}_{3}$, and $0.01 \mathrm{mmol}$ of $\mathrm{CuCl}_{2} \cdot 2 \mathrm{H}_{2} \mathrm{O}$. The $\mathrm{pH}$ was adjusted to $7.0\left(\right.$ at $25^{\circ} \mathrm{C}$ ) with $10 \%$ (wt/vol) $\mathrm{NaOH}$. The $\mathrm{pH}^{60 \mathrm{C}}$ of the autoclaved medium was 6.8 to 6.9 .

Enrichment and pure cultures were usually grown in $10 \mathrm{ml}$ of medium in Hungate tubes under a $100 \% \mathrm{CO}_{2}$ atmosphere. The medium was heat sterilized at $135^{\circ} \mathrm{C}$ for $30 \mathrm{~min}$. All incubations were at $60^{\circ} \mathrm{C}$ unless noted otherwise.

Determination of growth. Growth of bacteria was determined by direct counting with a phase-contrast microscope and a Petroff-Hausser chamber (Hausser Scientific Partnership, Horsham, Pa.) and by measuring the increase in optical density at $600 \mathrm{~nm}$ with a Spectronic 21 instrument (Bausch \& Lomb, Rochester, N.Y.).

$\mathrm{pH}$, temperature, and $\mathrm{NaCl}$ concentration ranges. The $\mathrm{pH}$ range for growth was determined at $60^{\circ} \mathrm{C}$. The $\mathrm{pH}^{60 \mathrm{C}}$, measured at $60^{\circ} \mathrm{C}$ and adjusted with sterile stock solutions of $\mathrm{HCl}$ or $\mathrm{NaOH}$, was determined with a model $815 \mathrm{MP}$ pH meter (Fisher Scientific, Pittsburg, Pa.) that was equipped with a temperature probe and had been calibrated at $60^{\circ} \mathrm{C}$. The temperature range for growth was determined by using a temperature gradient incubator (Scientific Industries, Inc., Bohemia, N.Y.) with shaking (15 strokes per min [spm]) in basal medium at $\mathrm{pH}^{60 \mathrm{C}} 6.8$. The effect of $\mathrm{NaCl}$ on growth was determined in basal media containing $0,0.5,1.0,1.5$, and $2.0 \%$ (wt/vol) $\mathrm{NaCl}$.

Substrate utilization. The ability of the organism to utilize different substrates was tested by using the basal medium amended with autoclaved or filter-sterilized substrates in lieu of glycerol. The potential for molecular hydrogen to serve as an electron donor was determined in $60-\mathrm{ml}$ flasks containing $10 \mathrm{ml}$ of medium and $\mathrm{H}_{2}-\mathrm{CO}_{2}(80: 20$ or $5: 95$, vol/vol) in the gas phase. The cultures were incubated for 2 weeks, and substrate utilization was monitored by measuring growth and production of acetate. Cultures with molecular hydrogen were incubated for 60 days, and consumption of $\mathrm{H}_{2}$ was monitored. Medium containing no $\mathrm{H}_{2}$ or organic carbon sources except $0.05 \%$ yeast extract served as a control.

In experiments with cell suspensions, the cells were anaerobically harvested by centrifugation from cultures grown in basal medium, resuspended in $10 \mathrm{ml}$ of basal medium without glycerol, and then incubated in Balch tubes filled with $\mathrm{CO}_{2}$ $(100 \%)$ with shaking $(60 \mathrm{spm})$ at $58^{\circ} \mathrm{C}$. The additions were as given in the text.

Electron acceptors. The potential use of different electron acceptors was studied in basal medium containing glycerol $(30 \mathrm{mM})$ as the electron donor 
(besides the potential donor yeast extract). The different electron acceptors were added from autoclaved stock solutions. No reducing agent was present in media containing $\mathrm{O}_{2}$, amorphous $\mathrm{Fe}$ (III) oxide, $\mathrm{Fe}$ (III) citrate, or $\mathrm{MnO}_{2}$. Both reduced and reducing-agent-free media were used in nitrate-amended experiments. Cultures grown in basal medium were used as inocula $(10 \%, \mathrm{vol} / \mathrm{vol})$. The use of the clectron acceptors $(20 \mathrm{mM})$ was monitored by measuring growth (for all acceptors), by measuring sulfide production (for sulfate, sulfite, thiosulfate, and elemental sulfur), by performing high-performance liquid chromatography (HPLC) (for fumarate), and by monitoring changes in the visible color of the medium or precipitate [for amorphous $\mathrm{Fe}$ (III) oxide, $\mathrm{Fe}$ (III) citrate, $\mathrm{MnO}_{2}$, and thiosulfate]

Antibiotic susceptibility. Susceptibility to antibiotics was determined by transferring an exponentially growing culture into fresh basal media containing filtersterilized antibiotics at a concentration of $100 \mu \mathrm{g} / \mathrm{ml}$. The cultures were incubated for 2 weeks.

Microscopy. Routine examinations and cell counting were performed by light microscopy with a model PM 10AD microscope (Olympus Optical Co., Ltd Tokyo, Japan) equipped with phase-contrast optics. Transmission electron microscopy was performed with a model JEM-100 CXII electron microscope (JEOL, Tokyo, Japan). The samples used for ultrathin sectioning were prepared by using uranyl acetate and lead citrate for poststaining as described by Spurr (23). Gram staining was performed by the Hucker method (8).

Analytical techniques. Determinations of glycerol, glucose, short-chain organic acids, and alcohols were performed by HPLC as previously described (24). Molecular hydrogen was analyzed by gas chromatography (24). Sulfide was determined by the method of Cord-Ruwisch (5).

G+C content of DNA. The DNA was isolated and purified by the $\mathrm{NaOH}$ method described by Mesbah et al. (17). The DNA was digested enzymatically, and the guanine-plus-cytosine $(\mathrm{G}+\mathrm{C})$ content was determined by separating the nucleosides by HPLC as described by Whitman et al. (26) and Mesbah et al. (17)

DNA extraction, sequencing, and analysis of $16 \mathrm{~S}$ rRNA genes. Genomic DNA was extracted from cell pellets by standard methods (16). The $16 \mathrm{~S}$ ribosomal DNA (rDNA) was amplified by PCR as described previously (10). The doublestranded PCR products were sequenced by using cycle sequencing and a model ABI 373 automated sequencer. The 16S rDNA sequences were aligned manually with a representative set of sequences obtained from the Ribosomal Database Project or from recent GenBank releases. The secondary structure was used as a guide to ensure that only homologous regions were compared. A total of 1,513 nucleotides were sequenced, and 1,302 nucleotides were used in the phylogenetic analysis. Chimeric molecules were checked for by using the secondary structure and computer analyses. Phylogenetic trees were constructed either by using evolutionary distance matrices and the algorithm of De Soete (7) or by performing a maximum-likelihood analysis with the program fastDNAml (19). Bootstrap values were obtained for the maximum-likelihood analysis by using 100 replicate trees and random addition of sequence.

Nucleotide sequence accession number. The $16 \mathrm{~S}$ rDNA sequence of strain JW/AS-Y $6^{\mathrm{T}}$ has been deposited in the GenBank database under accession no. U82327.

\section{RESULTS}

Enrichment and isolation. The basal medium containing glycerol was inoculated with ca. $10 \%(\mathrm{vol} / \mathrm{vol})$ of the sample and incubated at $60^{\circ} \mathrm{C}$ in the dark. After three subsequent transfers $(10 \%, \mathrm{vol} / \mathrm{vol})$, the enrichment culture was serially diluted to extinction. Light microscopic observation of the highest dilution tube positive for glycerol consumption $\left(10^{-7}\right)$ revealed that the dominant organism was a spore-forming rod. This culture was transferred $(10 \%, \mathrm{vol} / \mathrm{vol})$ into fresh basal medium, autoclaved at $121^{\circ} \mathrm{C}$ for $10 \mathrm{~min}$ to kill the vegetative cells, and subsequently incubated at $60^{\circ} \mathrm{C}$. After 2 weeks of incubation growth was obtained, and the culture was subsequently serially diluted to extinction into $1.5 \%$ Bacto Agarcontaining basal medium. Single colonies were picked and subcultured in liquid medium of the same composition. This procedure was repeated twice, after which the culture was considered to be pure and was designated strain JW/AS-Y6 ${ }^{\mathrm{T}}$.

Colony and cell morphology. In agar shake cultures colonies appeared after 3 or 4 days. The colonies were uniformly round, 1.0 to $1.5 \mathrm{~mm}$ in diameter, white, and not pigmented. The vegetative cells of strain JW/AS-Y $6^{\mathrm{T}}$ were straight rods, 0.4 to $0.6 \mu \mathrm{m}$ in diameter and 3.0 to $6.5 \mu \mathrm{m}$ long (Fig. 1A). The cells occurred singly, were peritrichous, (Fig. 2a), possessed fimbriae (Fig. 2b), and exhibited a slight tumbling motility. Strain JW/AS-Y $6^{\mathrm{T}}$ formed round refractile endospores 1.0 to $1.5 \mu \mathrm{m}$ in diameter in terminal swollen sporangia which were 2.0 to 2.5

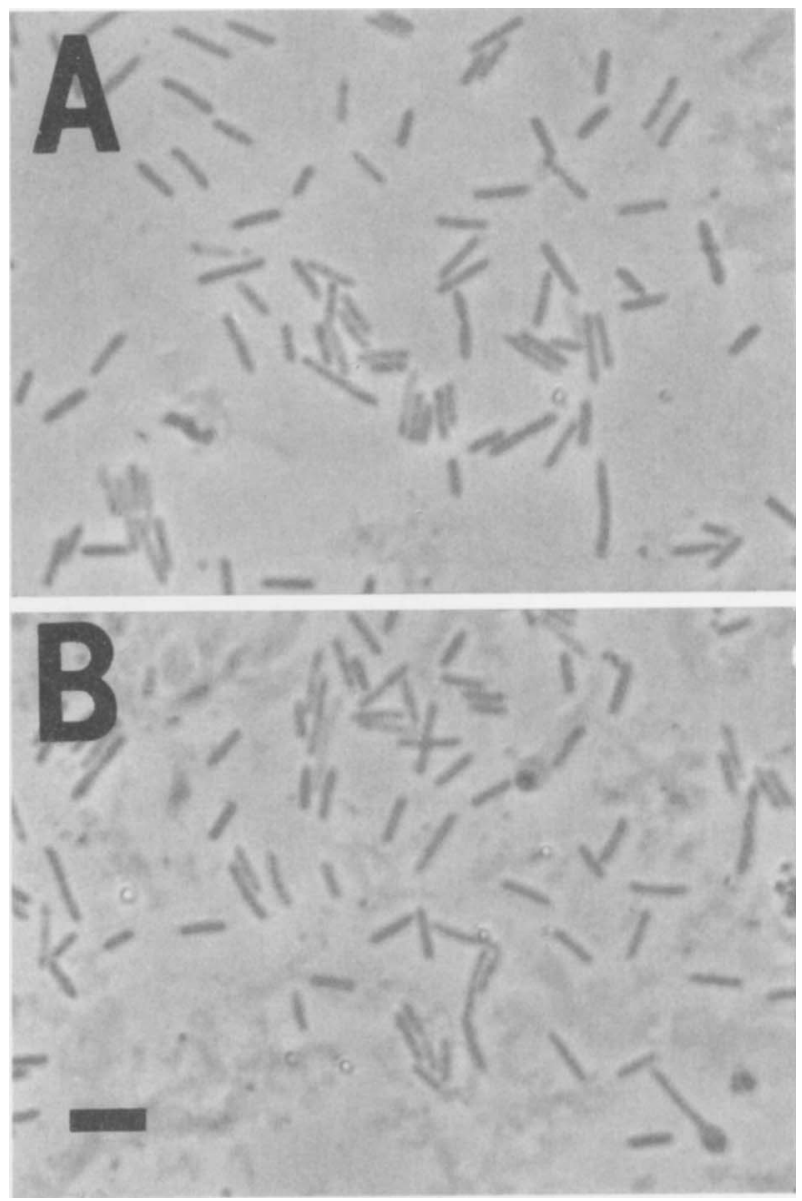

FIG. 1. Phase-contrast light micrograph of strain JW/AS-Y6 $6^{\mathrm{T}}$. (A) Vegetative cells in early exponential growth phase. (B) Vegetative and sporulating cells in late exponential growth phase. Bar $=5 \mu \mathrm{m}$.

$\mu \mathrm{m}$ in diameter. When the organism was grown in liquid basal medium, up to $5 \%$ of the cells sporulated during the late exponential phase (Fig. 1b).

Gram-staining reaction and Gram type. The cells stained gram positive in both the exponential and stationary growth phases. Since ultrathin sectioning of strain JW/AS-Y6 ${ }^{\mathrm{T}}$ (Fig. 3) also revealed a thick peptidoglycan, the organism is considered Gram type positive (27). This is consistent with the $16 \mathrm{~S}$ rRNA sequencing data which placed the organism in the ClostridiumBacillus subphylum. The cells contained an S-layer of the tetragonal type with a center-to-center measurement of around $10 \mathrm{~nm}$ for the subunit (Fig. 2c).

Temperature, $\mathrm{pH}$, and $\mathrm{NaCl}$ concentration ranges. The temperature range at $\mathrm{pH}^{60 \mathrm{C}} 6.8$ for growth of strain JW/AS-Y6 $6^{\mathrm{T}}$ was 43 to $65^{\circ} \mathrm{C}$, with optimum growth occurring at $58^{\circ} \mathrm{C}$ (Fig. 4). No growth was detected at $66^{\circ} \mathrm{C}$ or at temperatures of $42^{\circ} \mathrm{C}$ or lower after 3 weeks of incubation. The strain grew at $\mathrm{pH}^{60 \mathrm{C}}$ 5.9 to 7.8 , and optimum growth occurred at $\mathrm{pH}^{60 \mathrm{C}} 6.3$ to 6.5 (Fig. 5). No growth was detected at $\mathrm{pH}^{60 \mathrm{C}} 5.7$ and 8.0. Growth of strain JW/AS-Y $6^{\mathbf{T}}$ was observed in basal medium containing $\mathrm{NaCl}$ concentrations ranging from 0 to $2.0 \%$ (wt/vol), and no growth occurred in the presence of $2.5 \%$ (wt/vol) NaCl.

Substrate utilization and fermentation products. The substrates utilized included glycerol $(40 \mathrm{mM})$, glucose $(25 \mathrm{mM})$, fructose $(25 \mathrm{mM})$, mannose $(25 \mathrm{mM})$, galactose $(25 \mathrm{mM})$, xylose $(25 \mathrm{mM})$, lactate $(20 \mathrm{mM})$, glycerate $(20 \mathrm{mM})$, pyruvate 


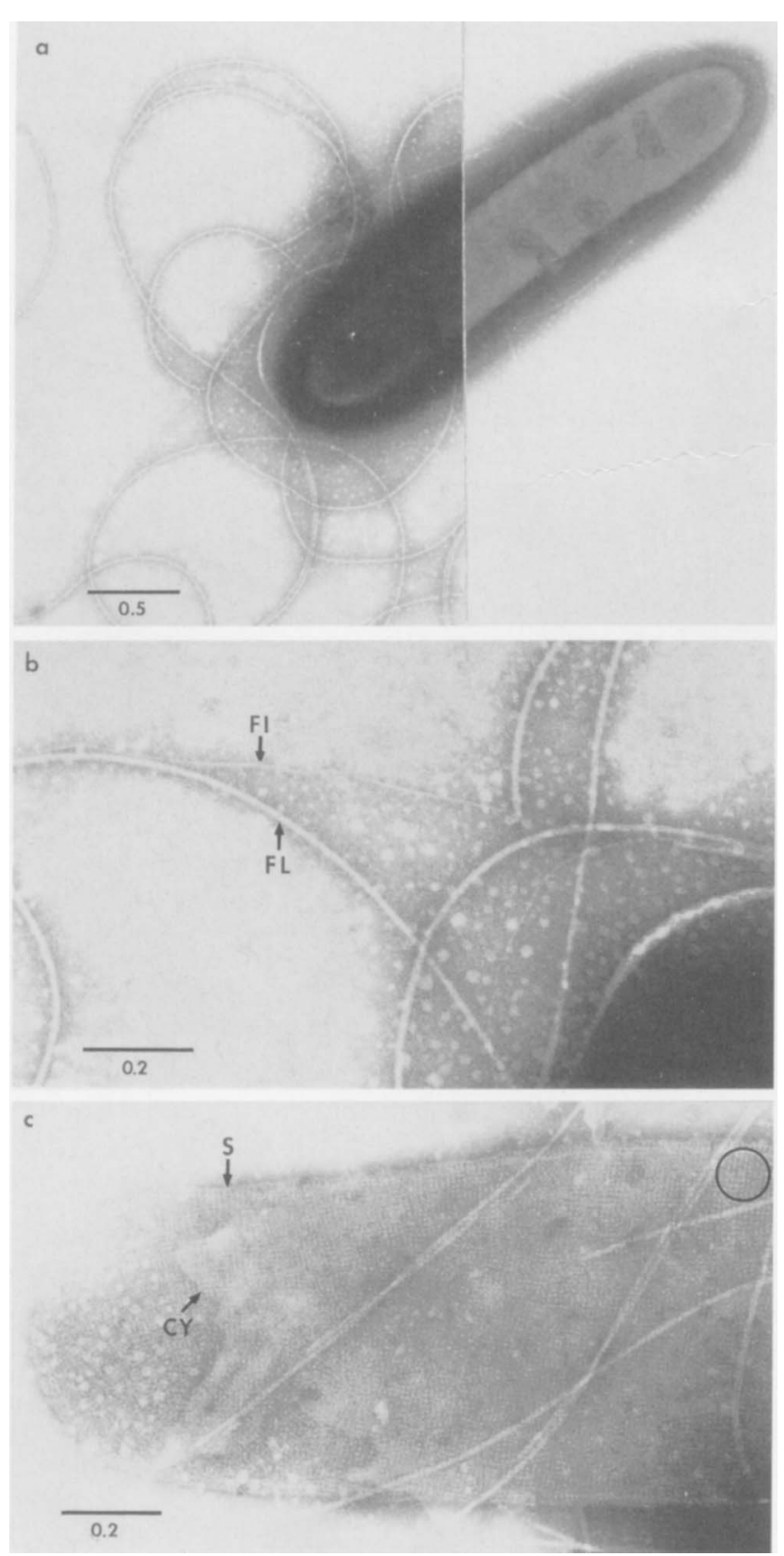

FIG. 2. Negative staining of strain JW/AS-Y $6^{\mathrm{T}}$. (a) Cell with peritrichously inserted flagella. Fimbriae are scarcely visible. The figure has been printed in such a way that the left part of the micrograph clearly shows the flagella, whereas the right part shows the cell envelope and the cytoplasm. Bar $=0.5 \mu \mathrm{m}$. (b) Higher magnification of part of panel a, showing fimbriae. FI, fimbria; FL, flagellum. Bar $=0.2 \mu \mathrm{m}$. (c) Cell from a sample harvested at the early stationary phase of growth. Cell lysis is evident. The surface layer $(S)$ is of the tetragonal type (circle). CY, remnants of the cytoplasm. Bar $=0.2 \mu \mathrm{m}$.

$(20 \mathrm{mM})$, and yeast extract $(5 \mathrm{~g} /$ /iter $)$. Strain JW/AS-Y6 $6^{\mathrm{T}} \mathrm{did}$ not use sucrose $(25 \mathrm{mM})$, cellobiose $(25 \mathrm{mM})$, arabinose $(25$ $\mathrm{mM})$, acetate $(30 \mathrm{mM})$, formate $(20 \mathrm{mM})$, methanol $(20 \mathrm{mM})$, ethanol (20 mM), $n$-propanol (20 mM), i-propanol (20 mM), $n$-butanol $(20 \mathrm{mM})$, propionate $(20 \mathrm{mM})$, acetone $(20 \mathrm{mM})$, fumarate $(20 \mathrm{mM})$, succinate $(20 \mathrm{mM})$, ethylene glycol $(20$ $\mathrm{mM})$, 1,2-propanediol (20 mM), 1,3-propanediol $(20 \mathrm{mM})$, phenol $(20 \mathrm{mM})$, benzoate $(20 \mathrm{mM})$, olive oil $(10 \mathrm{ml} / \mathrm{liter})$, and starch ( $5 \mathrm{~g} /$ liter $)$.
Strain JW/AS-Y6 ${ }^{\mathrm{T}}$ did not grow with $\mathrm{H}_{2}-\mathrm{CO}_{2}(80: 20$ or 5:95, $\mathrm{vol} / \mathrm{vol}$ ) when it was incubated in basal medium with or without glycerol or in basal medium without glycerol but supplemented with $20 \mathrm{mM}$ sodium acetate or $1.5 \mathrm{~g}$ of yeast extract per liter. Suspensions of cells $(0.9 \mathrm{~g}$ [dry weight]/liter) harvested in the exponential growth phase, however, did consume $\mathrm{H}_{2}$ and decreased the $\mathrm{H}_{2}$ concentration from an initial concentration of $1 \%(\mathrm{vol} / \mathrm{vol})$ to 0.19 to $0.24 \%$ when they were incubated with shaking for $64 \mathrm{~h}$.

In the presence of $\mathrm{CO}_{2}$, the only organic metabolic product of glycerol and glucose oxidation was acetate. Neither $\mathrm{H}_{2}$, $\mathrm{CH}_{4}, \mathrm{C}_{1}-\mathrm{C}_{3}$ alcohols, diols, nor organic acids other than acetate were detected in measurable amounts in these cultures at all growth stages. The ratio of amount of acetate produced to amount of glycerol consumed was $1.54 \pm 0.08$ (mean \pm standard deviation for five cultures) in cultures grown on basal medium. In cultures grown in medium supplemented with glucose $(10 \mathrm{mM})$ in the absence of yeast extract, the ratio of amount of acetate produced to amount of glucose consumed was $2.31 \pm 0.09$ (mean \pm standard deviation for five cultures). There was no growth of strain JW/AS-Y6 ${ }^{\mathbf{T}}$ if $\mathrm{CO}_{2}$ and $\mathrm{NaHCO}_{3}$ were omitted from the basal medium $\left(\mathrm{pH}^{60 \mathrm{C}}\right.$ was adjusted to 6.8 to 7.0 with $10 \mathrm{mM}$ MES [morpholineethanesulfonic acid] or $10 \mathrm{mM}$ HEPES [ $N$-2-hydroxyethylpiperazine$N^{\prime}$-2-ethanesulfonic acid]).

Electron acceptors. With glycerol as an electron donor, strain $\mathrm{JW} / \mathrm{AS}-\mathrm{Y}^{\mathrm{T}}$ reduced fumarate $(10 \mathrm{mM})$ to succinate and thiosulfate $(20 \mathrm{mM})$ to elemental sulfur. Strain JW/AS-Y6 ${ }^{\mathrm{T}}$ did not reduce nitrate $(20 \mathrm{mM}), \mathrm{MnO}_{2}(20 \mathrm{mM})$, amorphous Fe(III) oxide (90 mM), Fe(III) citrate $(20 \mathrm{mM})$, sulfate (20 $\mathrm{mM})$, or precipitated or sublimed $\mathrm{S}_{0}(150 \mathrm{mM})$ and was not capable of growth with $\mathrm{O}_{2}(20 \%$ [ $\mathrm{vol} / \mathrm{vol}]$ in the gas phase). Growth did not occur in oxidized medium, as indicated by the pink color of resazurin.

Antibiotic susceptibility. Ampicillin, chloramphenicol, erythromycin, rifampin, and tetracycline completely inhibited growth at a concentration of $100 \mu \mathrm{g} / \mathrm{ml}$ of medium. Streptomycin (100 $\mu \mathrm{g} / \mathrm{ml}$ ) did not inhibit growth.

DNA base composition. The $\mathrm{G}+\mathrm{C}$ content of the genomic DNA was $54.5 \pm 0.4 \mathrm{~mol} \%$ (as determined by HPLC).

Phylogeny. 16S rDNA sequence analysis indicated that strain JW/AS-Y6 ${ }^{\mathbf{T}}$ is a member of the Bacillus-Clostridium subphylum of the Gram type-positive (eu)bacteria (Fig. 6) and is closely related to Moorella thermoacetica (96.8\%) and Moorella thermoautotrophica. Trees based on maximum-likelihood analyses and distance matrices were identical. The bootstrap value (100 of 100 samplings) confirmed the affiliation of strain JW/AS-Y $6^{\mathrm{T}}$ with the genus Moorella.

\section{DISCUSSION}

The thermophilic, anaerobic, endospore-forming bacteria are currently placed in the genera Clostridium, Desulfotomaculum, Thermoanaerobacter, Thermoanaerobacterium, Caloramator, and Moorella $(3,14,29,30)$. The results of $16 \mathrm{~S}$ rDNA sequence analysis show that the bacteria most closely related to strain JW/AS-Y6 ${ }^{\mathrm{T}}$ are members of the genus Moorella. Furthermore, strain JW/AS-Y $6^{\mathrm{T}}$ is similar to both validly described Moorella species on the basis of its cell morphology, tetragonal type of S-layer, temperature optimum for growth, moles percent $\mathrm{G}+\mathrm{C}$ content of DNA, and homoacetogenic nature. Strain JW/AS-Y $6^{\mathrm{T}}$ differs from $M$. thermoacetica and $M$. thermoautotrophica in a number of physiological characteristics (Table 1). The most prominent differences are the ability of strain JW/AS-Y6 $6^{\mathrm{T}}$ to utilize glycerol, its inability to grow 


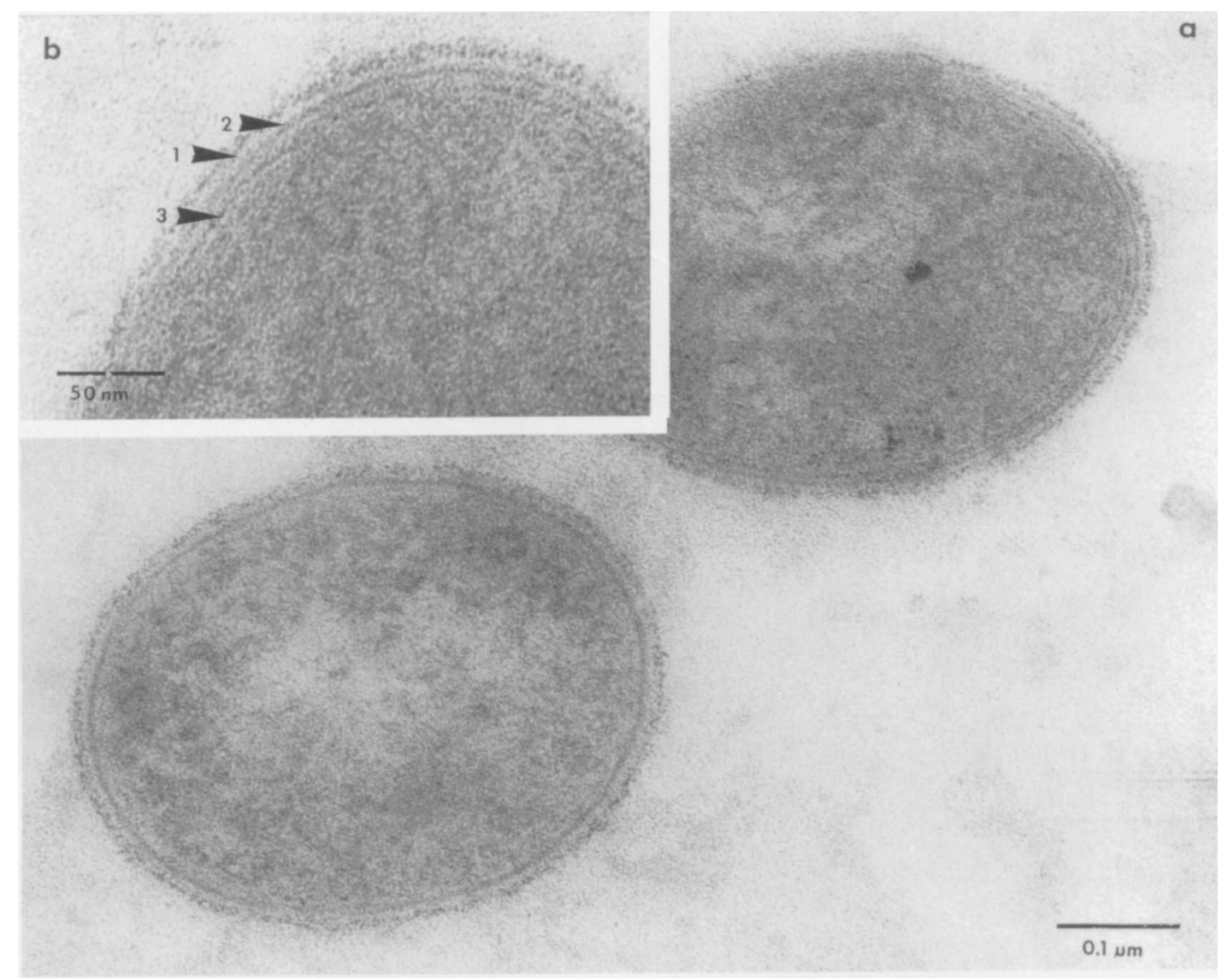

FIG. 3. Electron micrographs of ultrathin section of strain JW/AS-Y6 ${ }^{\mathrm{T}}$. (a) Cross section of two cells. (b) Higher magnification of part of panel a. Arrowhead 1 , outermost wall layer, presumably a surface layer (S-layer); arrowhead 2, thick peptidoglycan layer; arrowhead 3, cytoplasmic membrane.

with $\mathrm{H}_{2}-\mathrm{CO}_{2}$, and its ability to reduce thiosulfate to elemental sulfur.

The data obtained suggest that the glycerol utilization by strain JW/AS-Y $6^{\mathrm{T}}$ could be described by the following equation $(11,25): 4 \mathrm{C}_{3} \mathrm{H}_{8} \mathrm{O}_{3}+2 \mathrm{HCO}_{3}^{-} \rightarrow 7 \mathrm{C}_{2} \mathrm{H}_{3} \mathrm{O}_{2}^{-}+5 \mathrm{H}^{+}+$ $4 \mathrm{H}_{2} \mathrm{O}\left(\Delta \mathrm{G}^{0^{\prime \prime}}=-151.5 \mathrm{~kJ} / \mathrm{mol}\right.$ of glycerol $)$.

The genus Moorella was validly described by Collins et al. (3). This description was based on descriptions of Clostridium thermoaceticum (12) and Clostridium thermoautotrophicum (28) and included chemolithoautotrophic growth on $\mathrm{H}_{2}$ and

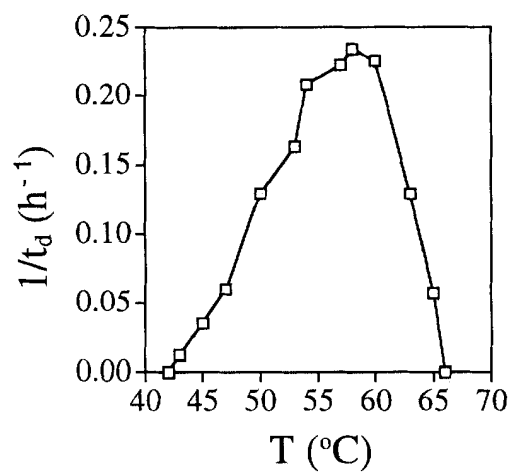

FIG. 4. Effect of temperature (T) on growth of strain JW/AS-Y6 ${ }^{\mathrm{T}}$. Absorbance was determined after $92 \mathrm{~h}$ of incubation; observed maximal cell densities were equivalent to an optical density at $600 \mathrm{~nm}$ of 0.220 .
$\mathrm{CO}_{2}$. C. thermoaceticum was originally described as a strict heterotroph, and it took 40 years to demonstrate that this organism possesses a hydrogenase (9), can utilize $\mathrm{H}_{2}(13)$, and can grow chemolithoautotrophically (6). Besides that, not all strains of $M$. thermoacetica are able to grow chemolithotrophically; of 13 strains tested, 3 lacked the ability to grow on $\mathrm{H}_{2}-\mathrm{CO}_{2}$. However, all of the strains exhibited homoacetogenic fermentation of glucose (6). In our hands, strain JW/AS-Y6 ${ }^{\mathrm{T}}$ did not grow chemolithoautotrophically at the expense of $\mathrm{H}_{2}-$ $\mathrm{CO}_{2}$; however, suspensions of cells in the exponential growth

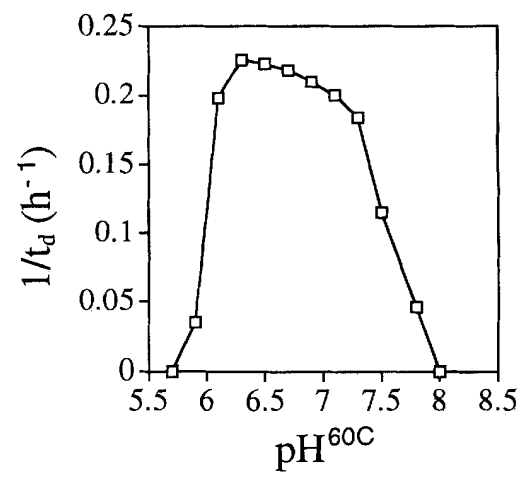

FIG. 5. Effect of $\mathrm{pH}^{60 \mathrm{C}}$ on growth of strain JW/AS-Y $6^{\mathrm{T}}$ at $60^{\circ} \mathrm{C}$. Absorbance was determined after $92 \mathrm{~h}$ of incubation; observed maximal cell densities were equivalent to an optical density at $600 \mathrm{~nm}$ of 0.240 . 


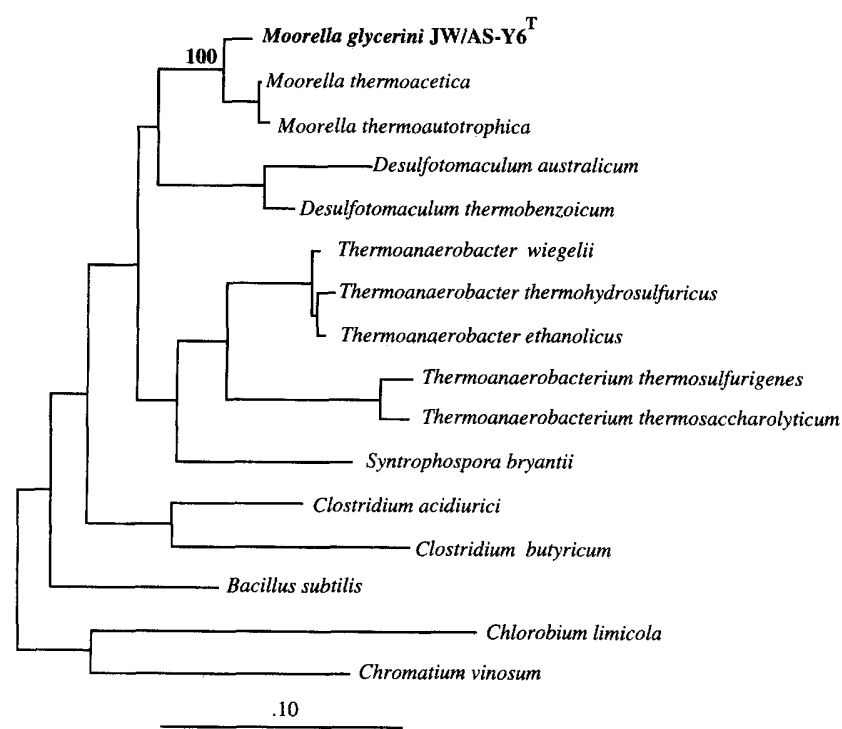

FIG. 6. Phylogenetic tree showing the position of $M$. glycerini JW/AS-Y ${ }^{\mathrm{T}}$. The tree was produced by maximum-likelihood analysis, and the bootstrap value was obtained for a bootstrap sampling of 100 . The scale bar represents the expected number of changes per sequence position.

phase consumed $\mathrm{H}_{2}$. We propose that strain JW/AS-Y6 ${ }^{\mathbf{T}}$ should be assigned to the genus Moorella as a member of a new species, Moorella glycerini, which is not able to grow chemolithoautotrophically.

Description of Moorella glycerini sp. nov. Moorella glycerini (gly.ce.ri'ni. Gr. adj. glykeros, sweet; M.L. adj. glycerini, of glycerol, referring to the utilization of glycerol as a substrate). Straight rods, 0.4 to 0.6 by 3.0 to $6.5 \mu \mathrm{m}$, that form round endospores that are 1.0 to $1.5 \mu \mathrm{m}$ in diameter in large terminal swollen sporangia (diameter, 2.0 to $2.5 \mu \mathrm{m}$ ). Cells stain gram positive. Cells occur singly and exhibit slight tumbling motility. Anaerobic and thermophilic. The temperature range for growth is 43 to $65^{\circ} \mathrm{C}$, and the optimum temperature is $58^{\circ} \mathrm{C}$. The $\mathrm{pH}^{60 \mathrm{C}}$ range for growth is 5.9 to 7.8 , and the optimum $\mathrm{pH}^{60 \mathrm{C}}$ is 6.3 to 6.5 . Growth occurs in the presence of $\mathrm{NaCl}$ concentrations of 0 to $2.0 \%$ (wt/vol). Able to grow with glycerol as the only organic carbon source; however, yeast extract stimulates growth. Utilizes glycerol, glucose, fructose, mannose, galactose, xylose, lactate, glycerate, pyruvate, and yeast extract. In the presence of $\mathrm{CO}_{2}$, acetate is the only organic product of glycerol and carbohydrate fermentation. $\mathrm{H}_{2}$ production from glucose and glycerol is not observed. Not able to grow chemolithotrophically at the expense of $\mathrm{H}_{2}-\mathrm{CO}_{2}$; however, suspen-

TABLE 1. Characteristics that differentiate $M$. glycerini from other members of the genus Moorella

\begin{tabular}{lcccc}
\hline \multicolumn{1}{c}{ Characteristic } & $\begin{array}{c}\text { M. glyc- } \\
\text { erini }\end{array}$ & $\begin{array}{c}\text { M. thermo- } \\
\text { acetica }\end{array}$ & $\begin{array}{c}\text { M. thermo- } \\
\text { autotrophica }\end{array}$ & $\begin{array}{c}\text { Refer- } \\
\text { ences }\end{array}$ \\
\hline $\begin{array}{l}\text { Growth on: } \\
\text { Glycerol }\end{array}$ & + & - & - & 2,28 \\
$\mathrm{H}_{2}$ & - & \pm & + & $6,13,28$ \\
Methanol & - & \pm & + & 6,28 \\
Lactate & + & - & + & 2,28 \\
Pyruvate & + & + & - & 2,28 \\
Reduction of $\mathrm{NO}_{3}{ }^{-}$ & - & + & + & 2,22 \\
Compound that $\mathrm{S}_{2} \mathrm{O}_{3}{ }^{2-}$ & $\mathrm{S}_{0}$ & $\mathrm{H}_{2} \mathrm{~S}$ & $\mathrm{H}_{2} \mathrm{~S}$ & 1,28 \\
$\quad$ is reduced to & & & & \\
\hline
\end{tabular}

sions of cells in the exponential growth phase consume $\mathrm{H}_{2}$. No growth occurs with sucrose, cellobiose, arabinose, acetate, formate, methanol, ethanol, $n$-propanol, i-propanol, $n$-butanol, propionate, acetone, fumarate, succinate, ethylene glycol, 1,2propanediol, 1,3-propanediol, phenol, benzoate, olive oil, and starch. Reduces fumarate to succinate and thiosulfate to elemental sulfur, but does not reduce nitrate, $\mathrm{MnO}_{2}$, amorphous $\mathrm{Fe}(\mathrm{III})$ oxide, $\mathrm{Fe}$ (III) citrate, sulfate, sulfite, or precipitated or sublimed $\mathrm{S}_{0}$. Growth is inhibited by ampicillin, chloramphenicol, erythromycin, rifampin, and tetracycline at a concentration of $100 \mu \mathrm{g} / \mathrm{ml}$ but not by streptomycin. The DNA base composition is $54.5 \pm 0.4 \mathrm{~mol} \% \mathrm{G}+\mathrm{C}$ (as determined by HPLC). The habitat is a freshwater hot spring (Calcite Spring area) at Yellowstone National Park, Wyo.

The type strain is JW/AS-Y6, which has been deposited in the German Culture Collection as strain DSM 11254.

\section{ACKNOWLEDGMENTS}

This work was supported by a grant to J.W. from Genencor International.

We thank N. Strutz and M. Dreier for electron microscopy and J. Spina for technical assistance. We are grateful for the sequencing and phylogenetic analysis assistance provided by J. Kirshtein and P. Rivera.

\section{REFERENCES}

1. Beaty, P. S., and L. G. Ljungdahl. 1991. Growth of Clostridium thermoaceticum on methanol, ethanol, propanol, and butanol in medium containing either thiosulfate or dimethylsulfoxide, abstr. K-131, p. 236. In Abstracts of the 91st Annual Meeting of the American Society for Microbiology 1991. American Society for Microbiology, Washington, D.C.

2. Cato, E. P., W. L. George, and S. M. Finegold. 1986. Genus Clostridium, p. 1141-1200. In P. H. A. Sneath, N. S. Mair, M. E. Sharpe, and J. G. Holt (ed.), Bergey's manual of systematic bacteriology, vol. 2. The Williams and Wilkins Co., Baltimore, Md.

3. Collins, M. D., P. A. Lawson, A. Willems, J. J. Cordoba, J. FernandezGarayzabal, P. Garcia, J. Cai, H. Hippe, and J. A. E. Farrow. 1994. The phylogeny of the genus Clostridium: proposal of five new genera and eleven new species combinations. Int. J. Syst. Bacteriol. 44:812-826.

4. Cook, G. M., F. A. Rainey, B. K. C. Patel, and H. W. Morgan. 1996. Characterization of a new obligately anaerobic thermophile, Thermoanaerobacter wiegelii sp. nov. Int. J. Syst. Bacteriol. 46:123-127.

5. Cord-Ruwisch, R. 1985 . A quick method for the determination of dissolved and precipitated sulfides in cultures of sulfide-reducing bacteria. J. Microbiol. Methods 4:33-36

6. Daniel, S. L., T. Hsu, S. I. Dean, and H. L. Drake. 1990. Characterization of the $\mathrm{H}_{2}$ - and $\mathrm{CO}$-dependent chemolithotrophic potentials of the acetogens Clostridium thermoaceticum and Acetogenium kivui. J. Bacteriol. 172:44644471 .

7. De Soete, G. 1983. A least squares algorithm for fitting additive trees to proximity data. Psychometrika 48:621-626.

8. Doetsch, R. N. 1981. Determinative methods of light microscopy, p. 21-33. In P. Gerhardt, R. G. E. Murray, R. N. Costilow, E. W. Nester, W. A. Wood, N. R. Krieg, and G. B. Phillips (ed.), Manual of methods for general microbiology. American Society for Microbiology, Washington, D.C.

9. Drake, H. L. 1982. Demonstration of hydrogenase in extracts of the homoacetate-fermenting bacterium Clostridium thermoaceticum. J. Bacteriol. 150: 702-709.

10. Durand, P., A. L. Reysenbach, D. Prieur, and N. Pace. 1993. Isolation and characterization of Thiobacillus hydrothermalis sp. nov., a mesophilic obligately chemolithotrophic bacterium isolated from a deep-sea hydrothermal vent in Fiji Basin. Arch. Microbiol. 159:39-44.

11. Eichler, B, and B. Schink. 1984. Oxidation of primary aliphatic alcohols by Acetobacterium carbinolicum sp. nov., a homoacetogenic anaerobe. Arch. Microbiol. 140:147-152.

12. Fontaine, F. E., W. H. Peterson, E. McCoy, M. J. Johnson, and G. J. Ritter. 1942. A new type of glycose fermentation by Clostridium thermoaceticum $n$. sp. J. Bacteriol. 43:701-715.

13. Kerby, R., and J. G. Zeikus. 1983. Growth of Clostridium thermoaceticum on $\mathrm{H}_{2} / \mathrm{CO}_{2}$ or $\mathrm{CO}$ as energy source. Curr. Microbiol. 8:27-30.

14. Lee, Y. E., M. K. Jain, C. Lee, S. E. Lowe, and J. G. Zeikus, 1993 Taxonomic distinction of saccharolytic thermophilic anaerobes: description of Thermoanaerobacterium xylanolyticum gen. nov., sp. nov., and Thermoanaerobacterium saccharolyticum gen. nov., sp. nov.; reclassification of Thermoanaerobium brockii, Clostridium thermosulfurogenes, and Clostridium thermohydrosulfuricum E100-69 as Thermoanaerobacter brockii comb. nov., 
Thermoanaerobacterium thermosulfurigenes comb. nov., and Thermoanaerobacter thermohydrosulfuricus comb. nov., respectively; and transfer of Clostridium thermohydrosulfuricum 39E to Thermoanaerobacter ethanolicus. Int. J. Syst. Bacteriol, 43:41-51.

15. Ljungdahl, L. G., and J. Wiegel. 1986. Anaerobic fermentations, p. 84-96. In A. L. Demain and N. A. Solomon (ed.), Manual of industrial microbiology and biotechnology. American Society for Microbiology, Washington, D.C.

16. Marmur, J. 1961. A procedure for the isolation of desoxyribonucleic acid from microorganisms. J. Mol. Biol. 3:208-218.

17. Mesbah, M., U. Premachandran, and W. B. Whitman. 1989. Precise measurement of $\mathrm{G}+\mathrm{C}$ content of deoxyribonucleic acid by high-performance liquid chromatography. Int. J. Syst. Bacteriol. 39:159-167.

18. Nilsen, R. K., T. Torsvik, and T. Lien. 1996. Desulfotomaculum thermocisternum sp. nov., a sulfate reducer isolated from a hot North Sea oil reservoir. Int. J. Syst. Bacteriol. 46:397-402.

19. Olsen, G. J., H. Matsuda, R. Hagstrom, and R. Overbeek. 1994. fastDNAml: a tool for construction of phylogenetic trees of DNA sequences using maximum likelihood. CABIOS 10:41-48.

20. Patel, B. K. C., H. W. Morgan, and R. M. Daniel. 1985. Fervidobacterium nodosum gen. nov., sp. nov., a new chemoorganotrophic, caldoactive, anaerobic bacterium. Arch. Microbiol. 141:63-69.

21. Rees, G. N., G. S. Grassia, A. J. Sheehy, P. P. Dwivedi, and B. K. C. Patel. 1995. Desulfacinum infernum gen. nov., sp. nov., a thermophilic sulfatereducing bacterium from a petroleum reservoir. Int. J. Syst. Bacteriol. 45: $85-89$.

22. Seifritz, C., S. L. Daniel, A. Gobner, and H. L. Drake. 1993. Nitrate as a preferred electron sink for the acetogen Clostridium thermoaceticum. J. Bacteriol. 175:8008-8013.

23. Spurr, A. R. 1969. A low-viscosity epoxy resin embedding medium for electron microscopy. J. Ultrastruct. Res. 26:31-43.

24. Svetlitshnyi, V., F. Rainey, and J. Wiegel. 1996. Thermosyntropha lipolytica gen. nov., sp. nov., a lipolytic, anaerobic, alkalitolerant thermophilic bacterium utilizing short- and long-chain fatty acids in syntrophic coculture with a methanogenic archaeum. Int. J. Syst. Bacteriol. 46:1131-1137.

25. Thauer, R. K., K. Jungermann, and K. Decker. 1977. Energy conservation in chemotrophic anaerobic bacteria. Bacteriol. Rev. 41:100-180.

26. Whitman, W. B., S. Sohn, D. S. Caras, and U. Premachandran. 1986. Isolation and characterization of 22 mesophilic methanococci. Syst. Appl. Microbiol. 7:235-240.

27. Wiegel, J. 1981. Distinction between the Gram reaction and the Gram type of bacteria. Int. J. Syst. Bacteriol. 31:88.

28. Wiegel, J., M. Braun, and G. Gottschalk. 1981. Clostridium thermoautotrophicum species novum, a thermophile producing acetate from molecular hydrogen and carbon dioxide. Curr. Microbiol. 5:255-260.

29. Wiegel, J. 1986. Genus Thermoanaerobacter, p. 1379-1383. In P. H. A Sneath, N. S. Mair, M. E. Sharpe, and J. G. Holt (ed.), Bergey's manual of systematic bacteriology, vol. 2. The Williams and Wilkins Co., Baltimore, Md.

30. Wiegel, J. 1992. The obligate anaerobic thermophilic bacteria, p. 105-184. In J. K. Kristjannson (ed.), Thermophilic bacteria. CRC Press, Boca Raton, Fla.

31. Wolin, E. A., M. J. Wolin, and R. S. Wolfe. 1963. Formation of methane by bacterial extracts. J. Biol. Chem. 238:2882-2886. 